\title{
NEW SEMISYNTHETIC DERIVATIVES OF A BENZYLISOTHIOCYANATE ISOLATED FROM Moringa oleifera AND EVALUATION OF THEIR CYTOTOXIC ACTIVITY
}

\author{
Diana Kelly C. de Almeida, ${ }^{a}$ Marcos R. da Silva, ${ }^{a}$ Maria Conceição F. de Oliveira, ${ }^{a}$ Jair Mafezoli, ${ }^{a}$ Marcos C. de Mattos,

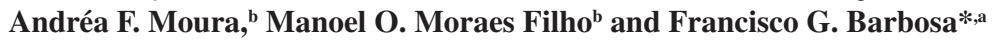 \\ a'Departamento de Química Orgânica e Inorgânica, Universidade Federal do Ceará, 60455-970 Fortaleza - CE, Brasil

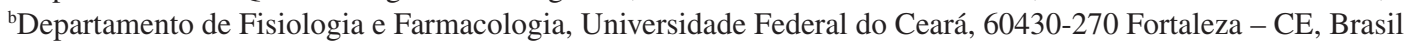

Recebido em 02/06/2017; aceito em 09/08/2017; publicado na web em 16/10/2017

\begin{abstract}
From the natural product 4-(4'-O-acetyl- $\alpha$-L- rhamnosyloxy)benzylisothiocyanate (1), isolated from the flowers of Moringa oleifera Lam (Moringaceae), four new semisynthetic derivatives, $N$-[4-(4'- $O$-acetyl- $\alpha$-L-rhamnosyloxy)benzyl]-2-(pyridinil-4-carbonil) hydrazine-1-carbothioamide (3), 4-(4'- $O$-acetyl-2',3'-dimesyloxy- $\alpha$-L-rhamnosyloxy)benzylisothiocyanate (4), $N$-[(4'- $O$-acetyl- $\alpha$-Lrhamnosyloxy)benzyl]hydrazinecarbothioamide (5), 4-[4'-O-acetyl-2',3'-O-bis(decanoiloxy)- $\alpha$-L- rhamnosyloxy]benzylisothiocianate (6), and the known compound 4-(2',3',4'-O-triacetyl- $\alpha$-L-rhamnosyloxy)benzylisothiocyanate (2), were obtained. All compounds were tested for their cytotoxicity against the tumor cell lines SF-295, HL-60, HCT-116 e PC-3. The natural product 1 and the semisynthetic derivatives $\mathbf{2}$ and $\mathbf{4}$ were the most active compounds $\left(\mathrm{IC}_{50}\right.$ from16.0 to $\left.3.7 \mu \mathrm{mol} \mathrm{L}^{-1}\right)$ against all tumor cell lines.
\end{abstract}

Keywords: benzylisothiocyanate; Moringa oleifera; cytotoxic activity; semisynthetic derivatives.

\section{INTRODUCTION}

Moringa oleifera Lam (Moringaceae) is an important medicinal plant from India which is cultivated in different parts of Middle East, America, Asia and Africa, where its flowers, leaves and seeds are used for human nutrition. ${ }^{1,2}$ This species is very well adapted in the Northeast region of Brazil, where its seeds are used to clear turbid waters to be consumed by human during the water scarcity. ${ }^{3}$

Several medicinal properties are described for different parts of $M$. oleifera ${ }^{1,2}$ such as antispasmodic, anti-inflammatory, diuretic, ${ }^{4}$ antimicrobial, ${ }^{5}$ antioxidant,${ }^{6,7}$ cytotoxic, ${ }^{7}$ hepatoprotective, hypoglycemic, hypolipidemic, ${ }^{8}$ anticancer, ${ }^{8,9}$ and antihypertensive. ${ }^{10}$ Studies on the antioxidant and antimicrobial activities of leaves from M. oleifera as feed for chickens validated the use of this plant in the animal nutrition. ${ }^{8,11}$

Varied classes of chemical compounds were isolated from $M$. oleifera, such as simple sugars, glucosinolates, amino acids, phenolic acids, alkaloids, flavonoids, steroids, carbamates, nitriles, thiocarbamates and isothiocyanates. ${ }^{1,2,8}$ It is worth pointing out the presence of thiocarbamates and isothiocyanates due to their biological activities. For example, the isothiocyanate 4-(4'- $O$-acetyl$\alpha$-L- rhamnosyloxy)benzylisothiocyanate (1), isolated from the ethanol extract from leaves of $M$. oleifera,${ }^{10}$ showed cytotoxic, hypotensive, antimicrobial and anti-inflammatory activities, ${ }^{1,2,10,12,13}$ and its deacetylated analog presented antitumor, antioxidants and anti-inflammatory activities. ${ }^{14}$

The chemical preparation of derivatives from natural bioactive products is a strategy used for the improvement and/or enhancement of biological activities, creation of biological screening libraries, as well as quantitative structure activity relationship (QSAR) studies. ${ }^{15,16}$ Herein, we report the isolation of isothiocyanate $\mathbf{1}$ from flowers of $M$. oleifera and the preparation of its derivatives 2-6 by semisynthesis. Additionally, all compounds were assayed against the tumor cell lines SF-295, HL-60, HCT-116 and PC-3.

*e-mail: fgerhar@gmail.com

\section{EXPERIMENTAL}

\section{Reagents and equipment}

All commercially available reagents were purchased from SigmaAldrich and used without further purification. The solvents were of analytical grade, freshly distilled, and dried on nitrogen atmosphere prior to use. Isolation and reactions were monitored by thin layer chromatography (TLC), performed on aluminum plates coated with silica gel GF-254 (Merck DC). The chromatographic procedures were carried out using silica gel 230-240 and 70-270 mesh (Acros Organics). Compounds were detected under a UV lamp (254 nm) and by spraying a solution of perchloric acid-vanilin in $\mathrm{EtOH}$, followed by heating. Melting points were determined on a Mettler Toledo FP62 apparatus, and are uncorrected. IR spectra were recorded on a Perkin-Elmer Spectrum 100 FT-IR spectrometer. Optical rotations were obtained on a Perkin-Elmer 341 polarimeters $(589 \mathrm{~nm}$ and room temperature). NMR spectra $\left({ }^{1} \mathrm{H},{ }^{13} \mathrm{C}\right.$, DEPT, COSY, HSQC and $\mathrm{HMBC}$ ) were recorded in $\mathrm{CD}_{3} \mathrm{OD}$ (Tedia, with TMS as internal standard) on Bruker Avance DPX $300(300 \mathrm{MHz})$ and Avance DPX $500(500 \mathrm{MHz})$ spectrometers. High-resolution MS were obtained on a Shimadzu LCMS-IT-TOF spectrometer equipped with an ESI source in positive and negative modes.

\section{Plant material}

The flowers of Moringa oleifera Lam. were collected at the Garden of Medicinal Plants Francisco José de Abreu Matos, Federal University of Ceará, in May 2012. A voucher specimen (\#38.195) was deposited at the Herbarium Prisco Bezerra from the Federal University of Ceará - Brazil.

\section{Extraction and isolation of compound 1}

A dry-powdered aliquot of flowers $(291.0 \mathrm{~g})$ were extracted with chloroform $(1.0 \mathrm{~L})$ at room temperature for 48 hours. After filtration, the solvent was removed by vacuum affording $3.78 \mathrm{~g}$ of chloroform extract (MFC). MFC was submitted to column chromatography on 
silica gel (70-270 mesh) column, using hexane (1.1 L), ethyl acetate $(0.8 \mathrm{~L})$ and methanol $(0.5 \mathrm{~L})$ as eluents. The subfraction eluted with ethyl acetate $(1.97 \mathrm{~g})$ was chromatographed on silica gel (70-270 mesh) column using hexane/EtOAc mixtures with increasing polarity. This procedure yielded a subfraction enriched with compound 1 (862 mg), which was subjected to flash chromatography using $\mathrm{CH}_{2} \mathrm{Cl}_{2} / \mathrm{EtOAc}$ (7:3 to 5:5) and provided pure compound 1 (600 mg; $15.87 \%$ yield).

4-(4'- $O$-acetyl- $\alpha$-L-rhamnosyloxy)benzylisothiocyanate (1): White solid. $R_{f}\left(50 \%\right.$ hexane/EtOAc): 0.31 . M.p.: $125.6-125.8^{\circ} \mathrm{C}$. IR $v_{\max } / \mathrm{cm}^{-1}:$ 3398, 2920, 2851, 2169, 2088, 1726, 1612, 1510, 1421, 1231 and $1012 \mathrm{~cm}^{-1} .{ }^{1} \mathrm{H}$ NMR $\left(\mathrm{CDCl}_{3}, 500 \mathrm{MHz}\right) \delta(\mathrm{ppm}): 1.19(\mathrm{~d}$, $3 \mathrm{H}, J=6.2 \mathrm{~Hz}), 2.15(\mathrm{~s}, 3 \mathrm{H}), 3.87(\mathrm{~m}, 1 \mathrm{H}), 4.10(\mathrm{dd}, 1 \mathrm{H}, J=3.5$ and $9.5 \mathrm{~Hz}), 4.17(\mathrm{~m}, 1 \mathrm{H}), 4.66(\mathrm{~s}, 2 \mathrm{H}), 4.91(\mathrm{t}, 1 \mathrm{H}, J=9.6 \mathrm{~Hz}), 5.57(\mathrm{~s}$, $1 \mathrm{H}), 7.08(\mathrm{~d}, 2 \mathrm{H}, J=8.6 \mathrm{~Hz})$ and $7.25(\mathrm{~d}, 2 \mathrm{H}, J=8.6 \mathrm{~Hz}) .{ }^{13} \mathrm{C} \mathrm{NMR}$ $\left(\mathrm{CDCl}_{3}, 125 \mathrm{MHz}\right) \delta(\mathrm{ppm}): 17.5,21.1,48.4,66.7,70.2,70.9,75.3$, 97.6, 116.8, 128.3, 128.6, 156.2 and 172.4; HRMS (ESI+): calcd. for $\mathrm{C}_{16} \mathrm{H}_{19} \mathrm{NO}_{6} \mathrm{SNa}^{+}\left(\mathrm{M}+\mathrm{Na}^{+}\right)$: 376.0831; found: 376.0848. Specific rotation: $-67.8\left(c 0.12, \mathrm{CHCl}_{3}\right)$.

\section{Preparation of compound 2}

The $O$-acetylation reaction was carried out in a round-bottom flask $(10.0 \mathrm{~mL})$ containing $0.085 \mathrm{mmol}(30.0 \mathrm{mg})$ of compound 1 dissolved in $1.0 \mathrm{~mL}$ of dry dichloromethane. Following, $0.85 \mathrm{mmol}$ $(80.0 \mu \mathrm{L})$ of acetic anhydride, $0.85 \mathrm{mmol}(118.0 \mu \mathrm{L})$ of triethylamine and $0.085 \mathrm{mmol}(10.4 \mathrm{mg})$ of DMAP were added to the flask. The mixture was stirred at room temperature for $3 \mathrm{~h}$. After that, the solvent was removed by vacuum and the crude product was purified by column chromatography over silica gel using hexane/EtOAc (3:2) as eluent to give compound 2 (35.6 $\mathrm{mg}, 96 \%$ yield).

4-(2',3',4'-O-triacetyl- $\alpha$-L-rhamnosyloxy)benzylisothiocyanate (2): Yellow oil. $R_{f}\left(60 \%\right.$ EtOAc/hexane): 0.58 . IR $v_{\max } / \mathrm{cm}^{-1}: 2925$, 2170, 2087, 1744, 1610, 1510, 1439, 1214 and $1032 \mathrm{~cm}^{-1} .{ }^{1} \mathrm{H}$ NMR $\left(\mathrm{CDCl}_{3}, 300 \mathrm{MHz}\right) \delta(\mathrm{ppm}): 1.21(\mathrm{~d}, 3 \mathrm{H}, J=6.2 \mathrm{~Hz}), 2.04(\mathrm{~s}, 3 \mathrm{H}), 2.06$ $(\mathrm{s}, 3 \mathrm{H}), 2.20(\mathrm{~s}, 3 \mathrm{H}), 3.97(\mathrm{~m}, 1 \mathrm{H}), 4.66(\mathrm{~s}, 2 \mathrm{H}), 5.16(\mathrm{t}, 1 \mathrm{H}, J=10$ $\mathrm{Hz}), 5.43(\mathrm{~s}, 1 \mathrm{H}), 5.46(\mathrm{~d}, 1 \mathrm{H}, J=1.7 \mathrm{~Hz}), 5.51(\mathrm{dd}, 1 \mathrm{H}, J=3.5$ and $10 \mathrm{~Hz}), 7.09(\mathrm{~d}, 2 \mathrm{H}, J=8.7 \mathrm{~Hz})$ and $7.26(\mathrm{~d}, 2 \mathrm{H}, J=8.7 \mathrm{~Hz}) .{ }^{13} \mathrm{C} \mathrm{NMR}$ $\left(\mathrm{CDCl}_{3}, 75 \mathrm{MHz}\right) \delta(\mathrm{ppm}) 17.6,20.9,21.0,21.1,48.4,67.5,69.1$, 69.8, 71.1, 95.8, 117.0, 128.6, 128.7, 156.0, 170.1, 170.2 and 170.3. HRMS $\left(\mathrm{ESI}^{+}\right)$: calcd. for $\mathrm{C}_{20} \mathrm{H}_{23} \mathrm{NO}_{8} \mathrm{SNa}^{+}\left(\mathrm{M}+\mathrm{Na}^{+}\right)$: 460.1048 ; found: 460.1103. Specific rotation: $+17.3\left(c 0.10, \mathrm{CHCl}_{3}\right)$.

\section{Preparation of compound 3}

Isoniazid $(0.17 \mathrm{mmol} ; 24.0 \mathrm{mg})$ was added to a round-bottom flask $(10.0 \mathrm{~mL})$ containing compound $\mathbf{1}(0.085 \mathrm{mmol} ; 30.0 \mathrm{mg})$ in $2.0 \mathrm{~mL}$ of dry THF. The mixture was stirred at room temperature until the final product formation, which was monitored by TLC. After solvent distillation, the crude product was purified by column chromatography over silica gel using EtOAc/MeOH (3:1) as eluent. Compound 3 (32.5 mg) was obtained in $78 \%$ yield.

$N$-[4-(4'- $O$-acetyl- $\alpha$-L-rhamnosyloxy)benzyl]-2-(pyridinil-4carbonil)hydrazine-1-carbothioamide (3): Yellow solid. $R_{f}(60 \%$ EtOAc/MeOH): 0.54. M.p.: $148.1-149^{\circ} \mathrm{C}$. IR $v_{\max } / \mathrm{cm}^{-1}: 3215,3155$, 2933, 1723, 1683, 1600, 1228 and $1023 \mathrm{~cm}^{-1} .{ }^{1} \mathrm{H}$ NMR (CD $\mathrm{OD}, 300$ MHz) $\delta(\mathrm{ppm}): 1.08$ (d, 3H, J=6.2 Hz), 2.08 (s, 3H), $3.76(\mathrm{~m}, 1 \mathrm{H})$, $3.98(\mathrm{~m}, 1 \mathrm{H}), 4.01(\mathrm{~m}, 1 \mathrm{H}), 4.78(\mathrm{~s}, 2 \mathrm{H}), 5.0(\mathrm{t}, 1 \mathrm{H}, J=9.6 \mathrm{~Hz}), 5.42$ $(\mathrm{s}, 1 \mathrm{H}), 7.01(\mathrm{~d}, 2 \mathrm{H}, J=8.6 \mathrm{~Hz}), 7.30(\mathrm{~d}, 2 \mathrm{H}, J=8.6 \mathrm{~Hz}), 7.85(\mathrm{~d}, 2 \mathrm{H}$, $J=5.0 \mathrm{~Hz})$ and $8.70(\mathrm{~d}, 2 \mathrm{H}, J=4.6 \mathrm{~Hz}) .{ }^{13} \mathrm{C} \mathrm{NMR}\left(\mathrm{CD}_{3} \mathrm{OD}, 75 \mathrm{MHz}\right)$ $\delta$ (ppm): 17.9, 21.1, 48.5, 68.5, 70.3, 72.2, 75.5, 99.9, 117.5, 123.3, 130.0, 133.9, 141.9, 151.1, 156.9, 167.4, 172.6 and 185.0. HRMS $\left(\mathrm{ESI}^{+}\right)$: calcd. for $\mathrm{C}_{22} \mathrm{H}_{26} \mathrm{~N}_{4} \mathrm{O}_{7} \mathrm{~S}\left(\mathrm{M}+\mathrm{Na}^{+}\right)$: 513.1420; found: 513.1475 . Specific rotation: $+51.5(c 0.12, \mathrm{MeOH})$.

\section{Preparation of compound 4}

Mesyl chloride $(0.425 \mathrm{mmol} ; 33.0 \mu \mathrm{L})$ and triethylamine $(0.425$ $\mathrm{mmol} ; 59.0 \mu \mathrm{L})$ were slowly added to a round-bottom flask $(50.0 \mathrm{~mL})$ containing $0.142 \mathrm{mmol}(50.0 \mathrm{mg}$ ) of compound 1 dissolved in $1.0 \mathrm{~mL}$ of dry dichloromethane. The mixture was stirred at $0^{\circ} \mathrm{C}$ for $5 \mathrm{~h}$. The solvent was removed by vacuum and the crude product was purified by column chromatography over silica gel using hexane/EtOAc (1:1) as eluent. Compound $4(39.5 \mathrm{mg})$ was obtained in $55 \%$ yield.

4-(4'-O-acetyl-2',3'-dimesyloxy- $\alpha$-L-rhamnosyloxy)benzylisothiocyanate (4): Yellow solid. $R_{f}(50 \%$ hexane/EtOAc): 0.38. M.p.: 67.8-68.0 ${ }^{\circ} \mathrm{C}$; IR $v_{\max } / \mathrm{cm}^{-1}: 2918,2849,2170,2087,1746,1611,1510$, 1422,1353 and $1173 \mathrm{~cm}^{-1} .{ }^{1} \mathrm{H}$ NMR $\left(\mathrm{CDCl}_{3}, 500 \mathrm{MHz}\right) \delta(\mathrm{ppm}): 1.08$ (d, 3H, J=6.2 Hz), 2.14 (s, 3H), 3.14 (s, 3H), 3.21 (s, 3H), 3.97 (m, $1 \mathrm{H}), 4.67(\mathrm{~s}, 2 \mathrm{H}), 5.15(\mathrm{t}, 1 \mathrm{H}, J=10 \mathrm{~Hz}), 5.19(\mathrm{~m}, 1 \mathrm{H}), 5.27(\mathrm{dd}, 1 \mathrm{H}$, $J=3$ and $10 \mathrm{~Hz}), 5.67(\mathrm{~s}, 1 \mathrm{H}), 7.09(\mathrm{~d}, 2 \mathrm{H}, J=8 \mathrm{~Hz})$ and $7.28(\mathrm{~d}, 2 \mathrm{H}$, $J=8 \mathrm{~Hz}) \cdot{ }^{13} \mathrm{C} \mathrm{NMR}\left(\mathrm{CDCl}_{3}, 125 \mathrm{MHz}\right) \delta(\mathrm{ppm}): 17.5,21.0,38.8,39.0$, 48.3, 67.6, 69.9, 74.2, 75.6, 96.1, 116.9, 128.7, 128.7, 128.7, 129.3, 156.7 and 169.9. HRMS (ESI $)$ : calcd. for $\mathrm{C}_{18} \mathrm{H}_{23} \mathrm{NO}_{10} \mathrm{~S}_{3} \mathrm{Na}^{+}\left(\mathrm{M}+\mathrm{Na}^{+}\right)$: 532.0727; found: 532.0735; Specific rotation: $+51.5\left(c 0.10, \mathrm{CHCl}_{3}\right)$.

\section{Preparation of compound 5}

Hydrazine $(0.17 \mathrm{mmol} ; 10 \mu \mathrm{L})$ was added to a round-bottom flask (10.0 mL) containing $0.085 \mathrm{mmol}(30.0 \mathrm{mg}$ ) of compound 1 dissolved in $2.0 \mathrm{~mL}$ of dry THF. The reaction system was stirred at room temperature and the product formation was monitored by TLC. Distilled water $(2.0 \mathrm{~mL})$ was added to the flask and the product was extracted by liquid-liquid partition with ethyl acetate $(3 \times 5 \mathrm{~mL})$. The solvent was removed and compound $\mathbf{5}$ ( $26.5 \mathrm{mg} ; 81 \%$ yield) was purified by column chromatography over silica gel using EtOAc as eluent.

$N$-[(4'- $O$-acetyl- $\alpha$-L-rhamnosyloxy)benzyl]hydrazinecarbothioamide (5): Yellow oil. $R_{f}\left(100 \%\right.$ EtOAc): 0.34 . IR $v_{\max } / \mathrm{cm}^{-1}: 3450$, 3400, 2915, 2895, 1700, 1635, 1530, 1505, 1250 and $1020 \mathrm{~cm}^{-1}$. ${ }^{1} \mathrm{H}$ NMR $\left(\mathrm{CD}_{3} \mathrm{OD}, 300 \mathrm{MHz}\right) \delta(\mathrm{ppm}): 1.23(\mathrm{~d}, 3 \mathrm{H}, J=6.2 \mathrm{~Hz}), 2.00$ (s, 3H), 3.46 (t, 1H, J=9.5 Hz) $3.65(\mathrm{~m}, 1 \mathrm{H}), 3.85(\mathrm{dd}, 1 \mathrm{H}, J=3.4$ and $9.6 \mathrm{~Hz}), 4.00(\mathrm{~m}, 1 \mathrm{H}), 4.81(\mathrm{~s}, 2 \mathrm{H}), 5.42(\mathrm{~s}, 1 \mathrm{H}), 7.04(\mathrm{~d}, 2 \mathrm{H}$, $J=8.6 \mathrm{~Hz})$ and $7.32(\mathrm{~d}, 2 \mathrm{H}, J=8.6 \mathrm{~Hz}) .{ }^{13} \mathrm{C} \mathrm{NMR}\left(\mathrm{CD}_{3} \mathrm{OD}, 75 \mathrm{MHz}\right)$ $\delta$ (ppm): 17.7, 25.2, 46.4, 70.7, 72.2, 72.3, 73.9, 99.5, 117.6, 129.8, 133.5, 156.4, 178.4 and 181.8. HRMS (ESI-) calcd. for $\mathrm{C}_{16} \mathrm{H}_{23} \mathrm{~N}_{3} \mathrm{O}_{6} \mathrm{~S}$ (M-H): 386.1386; found: 386.1400. Specific rotation: +15.3 (c 0.19, $\mathrm{MeOH})$.

\section{Preparation of compound 6}

DMAP (0.085 mmol; $10.4 \mathrm{mg})$ and decanoyl chloride $(0.85$ mmol; $176.0 \mu \mathrm{L})$ were added to a round-bottom flask $(10.0 \mathrm{~mL})$ containing compound $1(0.085 \mathrm{mmol} ; 30.0 \mathrm{mg})$ dissolved in $1.0 \mathrm{~mL}$ of dry $\mathrm{CH}_{2} \mathrm{Cl}_{2}$. This mixture was stirred at room temperature for $24 \mathrm{~h}$. After that, the solvent was removed by vacuum and the crude product was purified by column chromatography over silica gel using hexane/ EtOAc (9:1) as eluent to give compound 6 (28.5 mg; $51 \%$ yield).

4-[4'-O-acetyl-2',3'-O-bis(decanoiloxy)- $\alpha$-L-rhamnosyloxy] benzylisothiocianate (6): Colorless oil. $R_{f}(90 \%$ hexane/EtOAc): 0.41; IR $v_{\max } / \mathrm{cm}^{-1}: 2910,2825,2150,2090,1750,1615,1500,1490$ and $1210 \mathrm{~cm}^{-1} .{ }^{1} \mathrm{H}$ NMR $\left(\mathrm{CDCl}_{3}, 300 \mathrm{MHz}\right) \delta(\mathrm{ppm}): 0.88(\mathrm{t}, 6 \mathrm{H}, J=6.9$ $\mathrm{Hz}), 1.20(\mathrm{~d}, 3 \mathrm{H}, J=6.2 \mathrm{~Hz}), 1.27(\mathrm{~m}, 4 \mathrm{H}), 1.61(\mathrm{~m}, 4 \mathrm{H}), 1.67(\mathrm{~m}$, 4H), 2.04 (s, 3H), $2.26(\mathrm{t}, 4 \mathrm{H}, J=7.5 \mathrm{~Hz}), 2.44(\mathrm{t}, 4 \mathrm{H}, J=7.5 \mathrm{~Hz})$, $3.97(\mathrm{~m}, 1 \mathrm{H}), 4.66(\mathrm{~s}, 2 \mathrm{H}), 5.16(\mathrm{t}, 1 \mathrm{H}, J=10 \mathrm{~Hz}), 5.44(\mathrm{~m}, 1 \mathrm{H})$, $5.52(\mathrm{dd}, 1 \mathrm{H}, J=2.8$ and $10 \mathrm{~Hz}), 7.09(\mathrm{~d}, 2 \mathrm{H}, J=8.6 \mathrm{~Hz})$ and 7.25 $(\mathrm{d}, 2 \mathrm{H}, J=8.6 \mathrm{~Hz}) \cdot{ }^{13} \mathrm{C} \mathrm{NMR}\left(\mathrm{CDCl}_{3}, 75 \mathrm{MHz}\right) \delta(\mathrm{ppm}): 14.3,17.6$, 20.9, 22.8, 25.0, 25.2, 29.3, 29.5, 29.6, 32.1, 34.3, 48.4, 67.5, 68.9, 69.6, 71.1, 96.0, 117.0, 128.6, 128.7, 156.1, 170.0, 172.9 and 173.0. 
HRMS (ESI+): calcd. for $\mathrm{C}_{36} \mathrm{H}_{55} \mathrm{NO}_{8} \mathrm{SNa}^{+}\left(\mathrm{M}+\mathrm{Na}^{+}\right)$: 684.3648; found: 684.3656. Specific rotation: $+46.7\left(c 0.10, \mathrm{CHCl}_{3}\right)$.

\section{Cytotoxicity assay evaluation-MTT}

Cytotoxic assay was performed with four tumor cell line HCT116 (colon adenocarcinoma), HL-60 (leukemia), PC-3 (prostate) and SF-295 (glioma), provided by the National Cancer Institute (Bethesda, MD, USA). Cells were grown in RPMI-1640 medium supplemented with $2 \mathrm{~mm}$ glutamine, $10 \%$ fetal calf serum, $100 \mathrm{mg} /$ $\mathrm{mL}$ streptomycin, and $100 \mathrm{U} / \mathrm{mL}$ penicillin at $37{ }^{\circ} \mathrm{C}$ in a $5 \% \mathrm{CO}_{2}$ atmosphere. The cytotoxicity of all compounds was evaluated in vitro using the MTT [3-(4,5-dimethyl-2-thiazolyl)-2,5-diphenyl- $2 \mathrm{H}$ tetrazolium bromide] reduction assay. ${ }^{17}$ Cells were plated in 96-well plates $\left(\mathrm{HL}-600,3 \times 10^{6}\right.$ cell mL $\mathrm{mL}^{-1}$, SF-295 and PC-3 0,1 $\times 10^{6}$ cell mL $^{-1}$ per well and HCT-116 $0,7 \times 10^{5}$ cell $\left.\mathrm{mL}^{-1}\right)$. The tested compounds (25-50 $\mu \mathrm{g} \mathrm{mL}^{-1}$ ) dissolved in dimethyl sulfoxide (DMSO) were added to each well, using the high-throughput screening-biomek (HTS), and incubated for $72 \mathrm{~h}$. Doxorubicin was used as positive control. Control groups received the same amount of DMSO. After $69 \mathrm{~h}$ of incubation, the supernatant was replaced by fresh medium containing MTT $\left(0.5 \mathrm{mg} \mathrm{mL}^{-1}\right)$. Three hours later, the MTT formazan product was dissolved in $150 \mu \mathrm{L}$ of DMSO, and absorbance was measured at $595 \mathrm{~nm} . \mathrm{IC}_{50}$ (the concentration that inhibits growth in 50\%) was calculated, along with the respective 95\% CI (confidence interval), by non-linear regression using the software GraphPad Prism 5.0.

\section{RESULTS AND DISCUSSION}

The natural product 4-(4'- $O$-acetyl- $\alpha$-L-rhamnosyloxy) benzylisothiocyanate (1) was isolated from the chloroform extract of $M$. oleifera flowers $(3.78 \mathrm{~g})$ in about $15 \%$ yield. The semisynthetic derivatives of $\mathbf{1}$ were obtained from the modification of the rhamnoside moiety $(\mathbf{2}, \mathbf{4}$ and $\mathbf{6})$ and the isothiocyanate group (3 and 5) with yields ranging from 51 to $96 \%$ (Figure 1). Among the five derivatives obtained, only compound $\mathbf{2}$ has been previously described ${ }^{18}$ and compounds 3-6 are being reported for the first time.

The structures of compounds $\mathbf{3}$ and $\mathbf{5}$ were established based on their ${ }^{1} \mathrm{H}$ and ${ }^{13} \mathrm{C}$ NMR spectra. To compound $\mathbf{5}$, the reaction with hydrazine converted the isothiocyanate moiety into the hydrazinecarbothioamide group. In the ${ }^{1} \mathrm{H}$ NMR spectrum of $\mathbf{5}$, due to the anisotropic effect of the hydrazinecarbothioamide group, it was observed a change at the chemical shift of singlete H-7 ( $\delta 4.81)$ which was $\delta 4.66$ in 1 . The ${ }^{13} \mathrm{C}$ NMR spectrum showed the signal at $\delta 181.8$ (C-8), characteristic of the hydrazinecarbothioamide system, and the lack of the signal at $\delta 128.3$ characteristic of the isothiocyanate group. These chemical shifts confirmed the conversion of compound $\mathbf{1}$ into derivative $\mathbf{5}$.

The ${ }^{1} \mathrm{H}$ and ${ }^{13} \mathrm{C}$ NMR spectra of $\mathbf{3}$ showed the chemical shifts at $\delta 4.78(\mathrm{H}-7)$ and $\delta 185.0(\mathrm{C}-8)$, respectively, indicating the presence of the hydrazinecarbothioamide moiety in the molecule. In addition, the presence of the isonicotinoyl group was confirmed by the signals at $\delta 7.85(\mathrm{H}-11$ and $\mathrm{H}-14)$ and $\delta 8.70(\mathrm{H}-12$ and $\mathrm{H}-13)$ in the ${ }^{1} \mathrm{H}$ NMR spectrum, and by the signals at $\delta 123.3$ (C-11 and C-14), $\delta 141.9$ (C-10), $\delta 151.1$ (C-12 and C-13) and $\delta 167.4$ (C-9) in the ${ }^{13} \mathrm{C}$ NMR spectrum.

The derivatives $\mathbf{4}$ and $\mathbf{6}$ were obtained through the mesylation and esterification reactions on the rhamnoside moiety of $\mathbf{1}$, respectively. The signals at $\delta 3.14$ (H-9') and $\delta 3.21$ (H-10') observed in the ${ }^{1} \mathrm{H}$ NMR spectrum of $\mathbf{4}$ were associated to two methyl groups and indicated the mesylation of the two free hydroxyls of the rhamnoside group. The deshielded hydrogens at $\delta 5.19\left(\mathrm{H}-2^{\prime}\right), \delta 5.27\left(\mathrm{H}^{\prime} 3^{\prime}\right)$ and

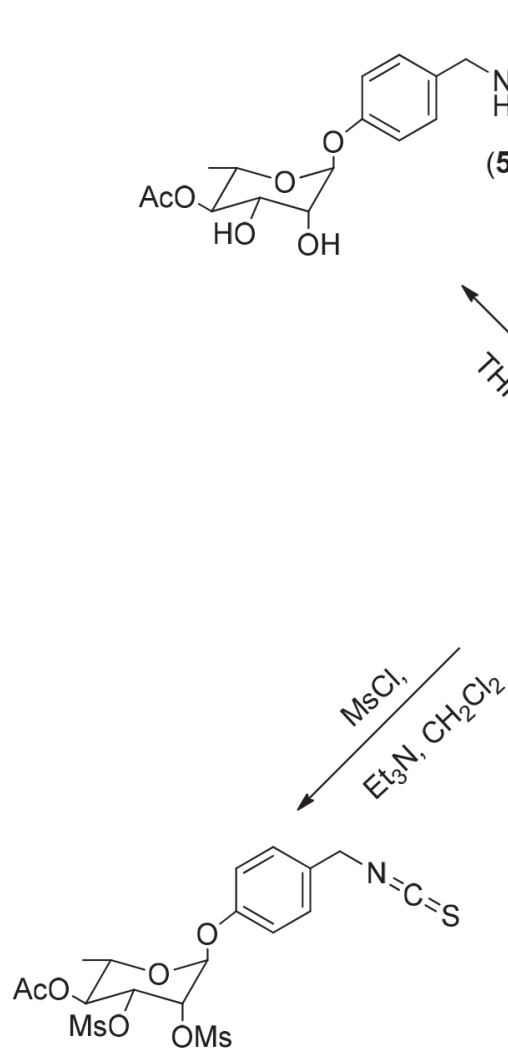

(4)<smiles>CNC(=S)NN</smiles><smiles>O=C(NNC(=S)NCc1ccc(O)cc1)c1ccncc1</smiles>
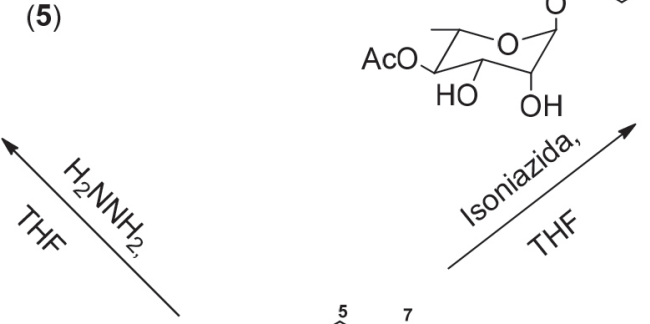

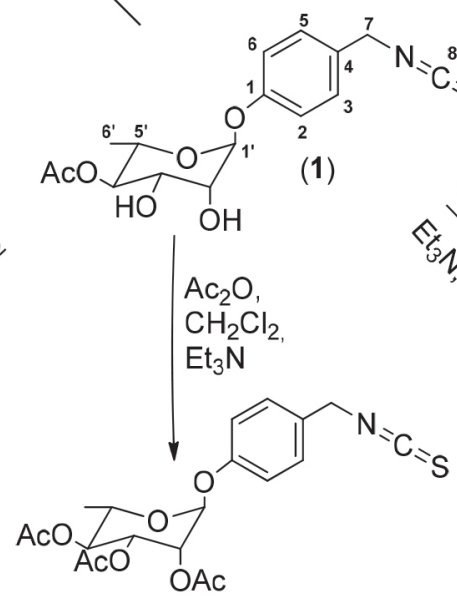

(2)<smiles>CC(=O)OC1OC(=O)OC(Oc2ccc(CN=C=S)cc2)C1OC(=O)O</smiles>

(6)

Figure 1. General scheme of the semisynthesis of derivatives 2-6 from 4-(4'-O-acetyl- $\alpha$-L-rhamnosyloxy)benzylisothiocyanate (1) 
$\delta 5.15\left(\mathrm{H}-4^{\prime}\right)$ corroborate these mesylations. In addition, the presence of the signals at $\delta 38.8$ and $\delta 39.0$ in the ${ }^{13} \mathrm{C}$ NMR spectrum of 4 confirmed the double mesylation. The double esterification of the rhamnoside moiety in $\mathbf{6}$ with the two decanoyl groups was confirmed by its ${ }^{1} \mathrm{H}$ NMR spectrum through the signals at $\delta 0.88$ associated to two methyl groups (H-18' and H-28'), and by the signals from $\delta 1.27$ to $\delta 2.44$ associated to the methylene groups. The esterification of the rhamnoside moiety with the decanoyl groups was also confirmed by the analysis of the ${ }^{13} \mathrm{C}$ NMR spectrum of $\mathbf{6}$ which showed the signals from $\delta 22.8$ to $\delta 34.3$, and at $\delta 172.9$ (C-19') and $\delta 173.0$ (C-9'), the two latter associated to two acyl groups.

\section{Cytotoxic activity and structure-activity relationship}

Studies on the cytotoxic activity of isothiocyanates (ITCs) and benzylisothiocyanate (BITC) have highlighted the importance of these classes of compounds as cancer chemopreventive agents ${ }^{19}$ and as inducer of apoptosis in cancer cells. ${ }^{20}$ The phenethyl isothiocyanate (PEITC) might be able to prevent cancer recurrence by suppressing cancer stem cells stemness. ${ }^{21}$ Additionally, the sulforaphene (an isothiocyanate present in radish plants) exhibits cytotoxic activity against breast cancer cells, which is associated with induction of the cell cycle arrest and apoptosis. ${ }^{22}$ It is worth mentioning that the naturally occurring isothiocyanate $\mathbf{1}$ showed significant inhibition $\left(\mathrm{IC}_{50} 1.0 \mu \mathrm{mol} \mathrm{L}-1\right)$ of the tumor-promoter induced Epstein-Barr virus activation. ${ }^{23}$ Thus, the natural product $\mathbf{1}$ and its semisynthetic derivatives 2-6 were assayed against the tumor cell lines SF-295, HL60, HTC-116 and PC-3, and the chemotherapy drug doxorubicin ${ }^{24}$ was used as positive control (Table 1). As far as we know, this is the first report on the cytotoxic activity of compounds 1-6 against these tumor cell lines.

The natural product 1 showed cytotoxicity against all tested cells lines with $\mathrm{IC}_{50}$ ranging from 5.4 to $13.8 \mu \mathrm{mol} \mathrm{L} \mathrm{L}^{-1}$, and corroborated previous results suggesting this class of natural products as cancer chemopreventive agents. ${ }^{19}$ Among the derivatives, only compounds 2 $\left(\mathrm{IC}_{50} 4.4-16.0 \mu \mathrm{mol} \mathrm{L}^{-1}\right)$ and $4\left(\mathrm{IC}_{50} 3.7-7.9 \mu \mathrm{mol} \mathrm{L}^{-1}\right)$ showed cytotoxic activity against all tested cell lines. In this case, both compounds were more active than the natural product when tested against the tumor cell lines HL-60 and HTC-116 (Table 1). Additionally, derivative 4 showed slightly lower $\mathrm{IC}_{50}\left(7.9 \mu \mathrm{mol} \mathrm{\textrm {L } ^ { - 1 }}\right)$ against the cell line SF295 when compared with the natural product $\left.1\left(\mathrm{IC}_{50} 10.2 \mu \mathrm{mol} \mathrm{L}\right)^{-1}\right)$. Derivatives $\mathbf{3}, \mathbf{5}$ and $\mathbf{6}$ were not cytotoxic as they showed $\mathrm{IC}_{50}>51.0$, 64.9 and $37.8 \mu \mathrm{mol} \mathrm{L}{ }^{-1}$, respectively.

Derivatives $\mathbf{3}$ and $\mathbf{5}$ are the only compounds that had chemical modification at the isothiocyanate moiety from their structures. Since both compounds were not cytotoxic, it is possible to corroborate that the isothiocyanate group is essential to the tested biological activity. As previously discussed by Murakami and co-workers, ${ }^{21}$ the carbon from the $-\mathrm{N}=\mathrm{C}=\mathrm{S}$ group is electrophilic and can react with nucleophiles ( $\mathrm{SH}$ and $\mathrm{OH}$ groups) from proteins in the biological systems. Nevertheless, derivative $\mathbf{6}$, which has the isothiocyanate moiety preserved in its structure, was not cytotoxic. In this case, the difference between the structures of $\mathbf{6}$ and the natural product $\mathbf{1}$ lies in the acylation of the rhamnoside moiety with two decanoyl groups in the derivative. Thus, the increment of both lipophilicity and steric hindrance of compound $\mathbf{6}$ may justify its lack of bioactivity. However, in order to support this hypothesis, additional derivatives will have to be prepared and evaluated. The preparation of derivatives $\mathbf{2}$ and $\mathbf{4}$ also involved modification in the rhamnoside moiety by protection of the two hydroxyls in $\mathbf{1}$ with acetyl and mesyl groups, respectively. In contrast to derivative $\mathbf{6}$, which was not bioactive, compounds $\mathbf{2}$ and $\mathbf{4}$ showed cytotoxicity and both were even more active than the natural product $\mathbf{1}$ against HL-60 and HTC-116 cell lines. In this case, it is possible to suggest that the slightly reduction of the polarity of the molecule without increasing much its volume is responsible for the higher cytotoxicity of both derivatives.

Table 1. Cytotoxic activity $\left(\mathrm{IC}_{50}\right.$ values in $\left.\mu \mathrm{mol} \mathrm{L}^{-1}\right)$ of 4-(4'-O-acetyl- $\alpha$-Lrhamnosyloxy)benzylisothiocyanate (1) and its semisynthetic derivatives 2-6 evaluated by the MTT assay after $72 \mathrm{~h}$ incubation

\begin{tabular}{|c|c|c|c|c|}
\hline \multirow[t]{2}{*}{ Compounds } & \multicolumn{4}{|c|}{$\begin{array}{c}\mathrm{IC}_{50}\left(\mu \mathrm{mol} \mathrm{L}^{-1}\right) \\
\text { 95\% Confidence intervals (CI 95\%) }\end{array}$} \\
\hline & SF-295 & HL-60 & НCТ-116 & PC-3 \\
\hline 1 & $\begin{array}{c}10.2 \\
(7.9-12.7) \\
\end{array}$ & $\begin{array}{c}7.4 \\
(5.7-9.3) \\
\end{array}$ & $\begin{array}{c}13.8 \\
(12.7-15.6) \\
\end{array}$ & $\begin{array}{c}5.4 \\
(5.1-6.2) \\
\end{array}$ \\
\hline 2 & $\begin{array}{c}16.0 \\
(11.6-22.7) \\
\end{array}$ & $\begin{array}{c}4.4 \\
(3.6-5.0) \\
\end{array}$ & $\begin{array}{c}8.9 \\
(6.6-11.9) \\
\end{array}$ & $\begin{array}{c}9.2 \\
(8.0-10.3) \\
\end{array}$ \\
\hline 3 & $>51.0$ & $>51.0$ & $>51.0$ & $>51.0$ \\
\hline 4 & $\begin{array}{c}7.9 \\
(7.1-8.9)\end{array}$ & $\begin{array}{c}3.7 \\
(3.2-4.7)\end{array}$ & $\begin{array}{c}4.3 \\
(3.5-5.1)\end{array}$ & $\begin{array}{c}5.9 \\
(5.5-6.5)\end{array}$ \\
\hline 5 & $>64.9$ & $>64.9$ & $>64.9$ & $>64.9$ \\
\hline 6 & $>37.8$ & $>37.8$ & $>37.8$ & $>37.8$ \\
\hline Doxorubicin $^{\mathrm{b}}$ & $\begin{array}{c}0.4 \\
(0.3-0.5)\end{array}$ & $\begin{array}{c}0.03 \\
(0.02-0.03)\end{array}$ & $\begin{array}{c}0.2 \\
(0.2-0.3)\end{array}$ & $\mathrm{NT}^{\mathrm{c}}$ \\
\hline
\end{tabular}

${ }^{a}$ HL-60 (leukemia); SF-295 (glioblastoma); HCT-116 (colon) e PC-3 (prostate). ${ }^{\mathrm{b}}$ Doxorubicin: positive control. ${ }^{\mathrm{c} N T}$ : not tested.

\section{CONCLUSIONS}

In summary, four derivatives (2-6) of the natural product 4-(4'-O-acetyl- $\alpha$-L-rhamnosyloxy)benzylisothiocyanate (1), isolated from $M$. oleifera, were prepared by semisynthesis. Among the derivatives, only compound $\mathbf{2}$ has been previously reported in the literature. All compounds were assayed against four tumor cell lines, and only the natural product $\mathbf{1}$ and its derivatives $\mathbf{2}$ and $\mathbf{4}$ were cytotoxic. Both derivatives were more active than the natural product 1 against HL-60 and HTC-116 tumor cell lines, suggesting that the slightly reduction of the polarity of the molecule without increasing much its volume may be responsible for the higher cytotoxicity of both derivatives. The chemical modification at the isothiocyanate moiety of the natural product yielded two derivatives ( 3 and $\mathbf{5}$ ) without cytotoxicity. This result corroborated the importance of the isothiocyanate moiety for the biological activity of the natural product.

\section{SUPPLEMENTARY MATERIAL}

Supplementary information, including NMR, IR and MS spectra (Figures 1S-29S), are available free of charge at http://quimicanova. sbq.org.br as PDF file.

\section{ACKNOWLEDGEMENTS}

The authors thank Conselho Nacional do Desenvolvimento Científico e Tecnológico (CNPq) for financial support (Process: 405001/2013-4) and Coordenação de Aperfeiçoamento de Pessoal de Nível Superior (CAPES) for providing sponsorship for D. K. C. Almeida. M. C. F. de Oliveira also thanks CNPq for the research grant (Process 303365/2014-5).

\section{REFERENCES}

1. Anwar, F.; Latif, S.; Ashraf, M.; Gilani, A. H.; Phytother. Res. 2007, 21, 17. 
2. Mishra, G.; Singh, P.; Verma, R.; Kumar, S.; Srivastav, S.; Jha, K. K.; Khosa, R. L.; Pharm. Lett. 2011, 3, 141.

3. Oliveira, J. T. A; Silveira, S. B.; Vasconcelos, I. M.; Cavada, B. S.; Moreira, R. A.; J. Sci. Food Agric. 1999, 79, 815

4. Cáceres, A.; Saravia, A.; Rizzo, S.; Zabala, L.; De Leon, E.; Nave, F.; J. Ethnopharmacol. 1992, 36, 233.

5. Velmurugan, S.; Elumalai, K.; Ravi, S.; Kathiravan, V.; Ashokkumar, S.; Spectrochim. Acta A 2015, 143, 158.

6. Santos, A. F. S.; Argolo, A. C. C.; Paiva, P. M. G.; Coelho, L. C. B. B.; Phytother. Res. 2012, 26, 1366.

7. Charoensin, S.; J. Med. Plants Res. 2014, 8, 318.

8. Leone, A.; Spada, A.; Battezzati, A.; Schiraldi, A.; Aristil, J.; Bertoli, S.; Int. J. Mol. Sci. 2015, 16, 12791.

9. Jung, I.; Lee, J. H.; Kang, S. C.; Oncol. Lett. 2015, 10, 1597.

10. Faizi, S.; Siddiqui, B. S.; Saleem, R.; Siddiqui, S.; Aftab, K.; J. Nat. Prod. 1994, 571256.

11. Jayawardana, B. C.; Liyanage, R.; Lalantha, N.; Iddamalgoda, S.; Weththasinghe, P.; Food Sci. Technol. 2015, 64, 1204.

12. Ghebremichael, K. A.; Gunaratna, R. R.; Henriksson, H.; Brumer, H.; Dalhammar, G.; Water Res. 2005, 39, 2338.

13. Cheenpracha, S.; Park, E. J.; Yoshida, W. Y.; Barit, C.; Wall, M.; Pezzuto, J. M.; Chang, L. C.; Bioorg. Med. Chem. 2010, 18, 6598.
14. Guevara, A. P.; Vargas, C.; Sakurai, H.; Fujiwara, Y.; Hashimoto, K.; Maoka, T.; Kozuka, M.; Ito, Y.; Tokuda, H.; Nishino, H.; Mutat. Res. 1999, 440, 181; Tumer, T. B.; Rojas-Silva, P.; Poulev, A.; Raskin, I.; Waterman, C.; J. Agric. Food Chem. 2015, 63, 1505; Waterman, C.; Cheng, D. M.; Rojas-Silva, P.; Poulev, A.; Dreifus, J.; Lila, M. A.; Raskin, I.; Phytochemistry 2014, 103, 114.

15. Singh, S. B.; Li, X.; Chen, T.; Tetrahedron Lett. 2011, 52, 6190.

16. Barnes, E. C.; Kumar, R.; Davis, R. A.; Nat. Prod. Rep. 2016, 32, 372.

17. Mosmann, T.; J. Immunol. Methods 1985, 65, 55.

18. Kjaer, A.; Malver, O.; El-Menshawi, B.; Reisch, J.; Phytochemistry 1979, 18,1485 .

19. Sibhatu, M. B.; Smitherman, P. K.; Townsend, A. J.; Morrow, C. S.; Carcinogenesis 2008, 29, 807.

20. Kalkunte, S.; Swamy, N.; Dizon, D. S.; Brard, L.; J. Exp. Therapeut. Oncol. 2006, 5, 287.

21. Yun, J. H.; Kim, K.-A; Yoo, G.; Kim, S. Y.; Shin, J. M.; Kim, J. H.; Jung, S. H.; Kim, J.; Nho, C. W.; Phytomedicine 2017, 30, 42.

22. Pawlika A, Wałaa, M.; Haća, A.; Felczykowska, A.; HermanAntosiewicz, A.; Phytomedicine 2017, 29, 1.

23. Murakami, A.; Kitazono, Y.; Jiwajinda, S.; Koshimizu, K.; Ohigashi, H.; Planta Med. 1998, 64, 319.

24. Tacar, O.; Sriamornsak, P.; Dass, C. R.; J. Pharm. Pharmacol. 2013, 65, 157. 